ve spolupráci s Nakladatelstvím Pavel Mervart. Hlavní redaktor časopisu a zároveň předseda organizačního výboru konference PhDr. Jindřich Kesner, CSc., vyzval účastníky a účastnice konference k participaci na obsahu druhého čísla časopisu, které bude vydáno ještě letos. Výstupem letošní konference se má také stát sborník př́spěvků účastníků jubilejního desátého Dialogu kultur.

Jaroslav Sommer - Polina Zolina

https://doi.org/10.5817/NR2019-1-14

\section{Konference Hodnoty v literatuře a v umĕní počtvrté}

Když se v roce 2012 konala první konference o hodnotách v literatuře a v umění pořádaná společně Ústavem slavistiky Filozofické fakulty Masarykovy univerzity a Českou asociací slavistů, šlo o malý test, nakolik může být takové téma zajímavé $\mathrm{v}$ době, kdy vrch zdánlivě berou postmoderní tendence hodnoty nivelizovat a stírat, kdy připomenout je znamená málem něco jako návrat $\mathrm{k}$ ruinám památek středověku. Zájem ovšem byl, byla i ochota organizátorů pokračovat. Následovaly konference v letech 2014 a 2016 - a vytvořilo se „jádro“ těch, kteř́i přijížděli opakovaně a měli zájem $\mathrm{v}$ diskusi o hodnotách pokračovat. Ve dnech 29.-30. srpna 2018 se konala takto tematicky pojatá konference již počtvrté a s rekordním zájmem o účast v ní.

Čtvrtý ročník konference využil toho, co se osvědčilo již v jejím předchozím běhu: mimo relativně volně pojaté panely zařadil i panely orientované tematicky na tvorbu V. M. Garšina, I. S. Turgeněva a pak také na dva obecněji pojaté okruhy, v nichž bylo možno se zaměřit na axiologické aspekty odrazu občanské války 1918-1922 v literárních dílech a na axiologické otázky ruské literární kritiky 19. století.

Konference se osobně zúčastnilo na šedesát badatelů ze Slovenska, Ruska, Polska, Izraele, Madarska, Německa, Gruzie, Běloruska, Ukrajiny, Bulharska a Kazachstánu, přičemž řada dalších zájemců poslala svá vystoupení v písemné podobě, protože jim osobní, termínové či finanční okolnosti neumožnily prijet.

Sám program konference, kterou hostila Filozofická fakulta Masarykovy univerzity, probíhal v celkem devíti sekcích orientovaných především na ruskou literaturu 19. a 20. století, výrazný vzestup zájmu bylo možno ale vidět i v sekci věnované jiným evropským literaturám a sekci, která sledovala „vyzařování" literatury směrem k jiným druhům umění a $\mathrm{k}$ výchovné, resp. školské praxi.

Jednání jednotlivých sekcí zahrnovala tematicky blízké okruhy spjaté zájmem o zachycení celé řady dílčích hodnotových aspektů, prričemž akcentovány byly otázky především etického, filozofického a uměleckého charakteru, prosazovaly se 
i širší kulturologické aspekty zpravidla pak v komparativním pohledu, a to jak rusko-českém, tak ve srovnávání ruského prostředí a ruské literatury s literaturami evropskými. Sevřeněji v tomto ohledu působily především ucelenější př́spěvky $\mathrm{v}$ tematicky zaměřených sekcích, prričemž relativně opatrný prrístup panoval při sledování tématu občanské války v Rusku, tedy velmi složité etapy historického vývoje, která je přece jen dodnes silně vázána ideologicky podbarvenými hodnoticími principy. Podstatně pestř̌ejší spektrum témat i názorů pak nabídl program sekce orientované na axiologické aspekty ruské literární kritiky 19. století, kam výrazněji pronikaly kulturologické i metodologické prvky. Do živé diskuse ústily referáty týkající se konkrétních problémů tvorby I. S. Turgeněva a V.M. Garšina každý z přednesených př́spěvků byl komentován a mnohdy $\mathrm{v}$ diskusi doplňován podněty zúčastněných. V sekcích, $\mathrm{v}$ nichž byly zařazeny př́spěvky studující konkrétní otázky vývoje ruské literatury 19.-21. století, se pozornost referujících často zaměřovala na jevy nejednoznačné, rozporné, související se širším humanitním záběrem, což jednak poskytovalo prostor pro diskusi, jednak vytvářelo podněty pro otevírání dalších tematických okruhů.

Zmiňovat konkrétní vystoupení asi není $\mathrm{v}$ hodnocení konference ideální - museli bychom uvést príliš mnoho jmen i témat jejich vystoupení a určitě bychom někoho neprávem vynechali to vše pak poskytne již připravovaný konferenční sborník. Zůstaneme proto u několika obecnějších postřehů. Určitě platí, že se kolem takto tematicky zaměřené série konferenčních setkání vytváří okruh badatelů, kterým je axiologie blízká a kteří považují hodnotové aspekty ve studiu literatury za důležité - potěšitelný je v tomto ohledu rostoucí zájem „mladé generace“, tedy doktorandů/aspirantů. Ukazuje se rovněž, že je smysluplné vyhledávat kromě obecnějších tematických okruhů i př́ležitost pro badatele, kteř́ axiologickou problematiku spojují s dílčími otázkami studia konkrétních historicky či jinak vymezených fenoménů, anebo pak s díly konkrétních spisovatelů. Dalším poznatkem je, že relativně komorní atmosféra, kterou konference tradičně mají, je něco, co je účastníky pozitivně hodnoceno zejména proto, že „neoficiálnost“ vytváří výborné podmínky pro nekonfrontační diskuse a vede k navazování nových kontaktů, $\mathrm{k}$ možnosti kuloárních diskusí a předávání zkušeností i námětů. Tomu pak posloužila i již tradiční prezentace publikačních výstupů pracovníků Ústavu slavistiky FF MU, která pořádající ústav prezentovala jako pracoviště, které zaujímá v rámci české slavistiky jedno z čelních, ne-li nejčelnější místo.

Zdá se tedy, že dosavadní růst zájmu podněcuje $\mathrm{k}$ přemýšlení o zaměření dalšího běhu konference, který by se měl při zachování stávajícího rytmu konat $\mathrm{v}$ roce 2020. Alespoň podle vyjádření většiny účastníků by minulá „čtyřka“ neměla zůstat poslední.

Josef Dohnal 